\title{
Analysis on Determining of the Purchase Price in the Repurchase Stage of a BT Project: A Case of Rail Transportation Project
}

\author{
Wei Zhong, Teng-teng Jiang \\ Management School, Tianjin University of Technology, Tianjin 300384, China
}

\begin{abstract}
The core issue about the risk management of the BT project was discussed in this paper, which presented the schemes of risk allocation between the government and the contractor. According to the analysis on the relationship of the risk factors bore by the government and the purchase price, the calculating method of purchase price were summarized and contrasted. Lastly, in the light of above analysis result, a case study was involved in this dissertation to verify the aforementioned research results.
\end{abstract}

Keywords-BT project; risk allocation; purchase price; financing charge.

\section{INTRODUCTION}

Project Financing is a financing or pattern of lending with or without recourse which is using specific project assets, expected earnings or rights as mortgage. Generally it is used in power generation, road, railway, airport, bridges and other big infrastructure projects with stable cash flow. It provides a more flexible form of financing for government construction projects and can meet the special requirements of the government in terms of capital. BT is a project construction financing mode which is widely adopted by domestic governments recently[1]. It can help government alleviating the huge infrastructure investment pressure greatly, improving the infrastructure construction and utilization efficiency as well as diversifying the risks of infrastructure construction[2]. Normally BT mode is not required to guarantee by the government, also, it cannot increase the foreign debt and affect the government's ownership of the project. Instead, all parties are involved in the risk allocation.

Domestic scholars have done a lot of research on the BT mode, especially for the current situation of BT risk management[3]. They also have studied and discussed the various risks in the project and the risks involved in the repurchase stage. But there are few studies about the factors that influence repurchase in the repurchase stage of a BT and problems such as how to determine the optimal repurchase price. Besides, although some regions have made provisions for the repurchase price and period in regulations, there is no unified conclusion. Especially there are no provisions for options of repurchase payment. They don't completely stand in the perspective of the government on how to select the optimal scheme in different repurchase period and repurchase pattern and there is no comprehensive and applicable theory system formed. Through introducing the BT project operation process, as well as the problems about project operation risks, the risk sharing scheme is put forward in this paper. Especially in the analysis of the owners' risks in the repurchase period and on how to solve the problems of determining repurchase price in the repurchase stage based on the perspective of the owner.

\section{ANALYSIS OF THE EACH STAGE OF BT PROJECT OPERATION PROCESS}

The international operation of BT mode is generally invested, financed, designed and constructed by BT project company. Inspection, design and supervision of general BT project is entrusted by the owner, and the BT project company constructs only according to the drawings, similar to the underwritten. Currently in China there is no explicit laws and regulations to standardize the BT project stages, but the local government has introduced trial measures for BT mode of construction management. From the provisions of various regions, division of domestic BT project operation process is consistent. Literature [4] introduced general operation process of BT mode.

This paper believed that the construction period of BT is started since the project is determined to use BT mode. According to the characteristics of engineering project construction process and $\mathrm{BT}$ project itself, the $\mathrm{BT}$ project is mainly divided into earlier stage, middle stage and later stage. The earlier stage includes the project establishment, project preparation, project bidding and project financing. The middle stage includes the construction implementation of the project. The later stage includes the transfer and repurchase of the project. The basic flow is shown in Figure.1 


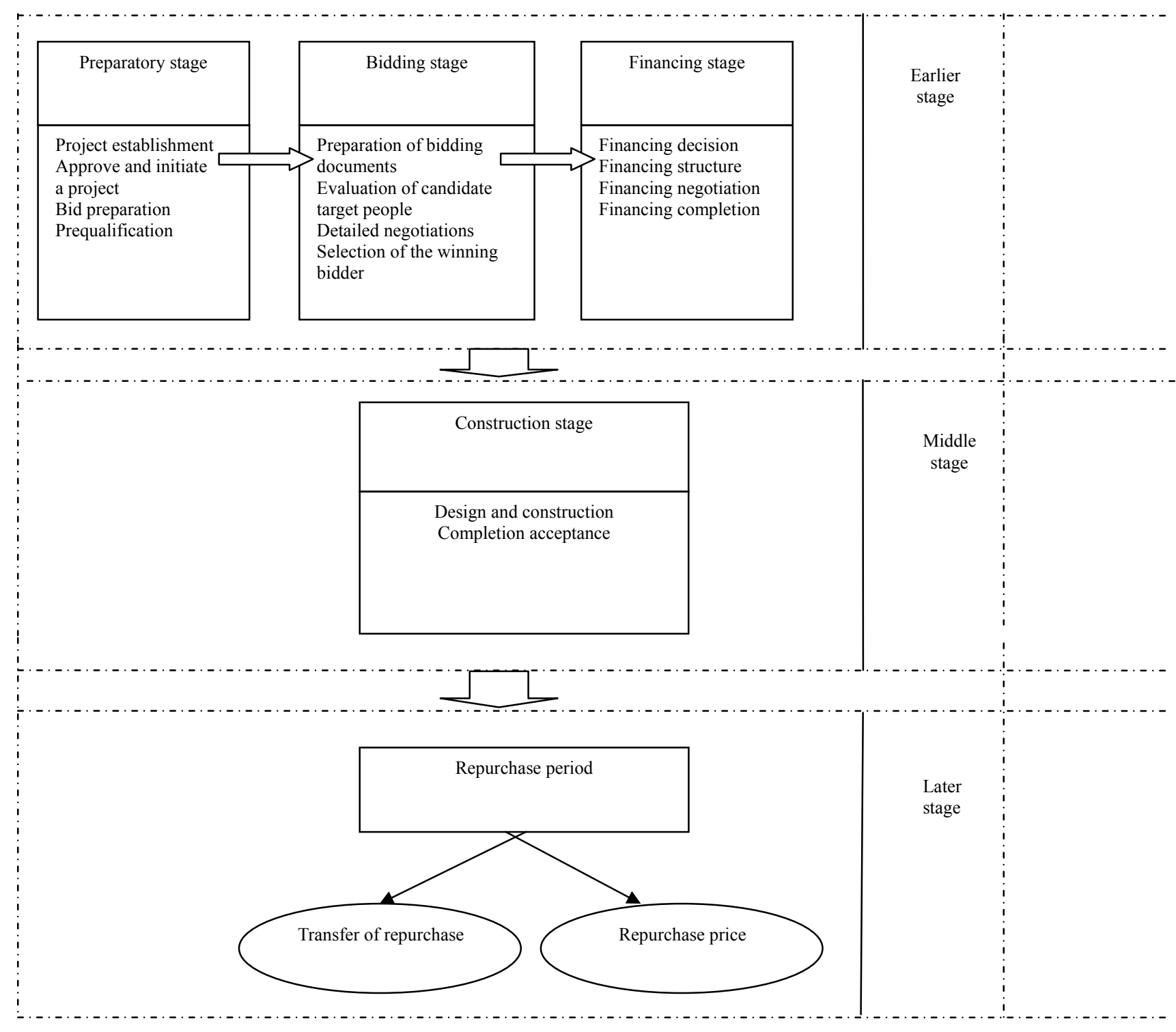

Figure 1. BT project operation process

III. ANALYSIS OF THE OWNER'S RISK IN THE REPURCHASE STAGE

According to the risk allocation scheme above between the owner and the Investor, both the owner and the investor take a risk in the whole life period of BT, especially the owner in repurchase stage. The main risks of the owner in the repurchase period are [5]: (1) Risks of low rates of return; (2)Economic risks; (3)Policy risks; (4)Construction quality risks; (5)Duration risks; (6)Risks of breaking a contract by the investor; (7)Risks of the investor's construction projects deviating from the design idea. 


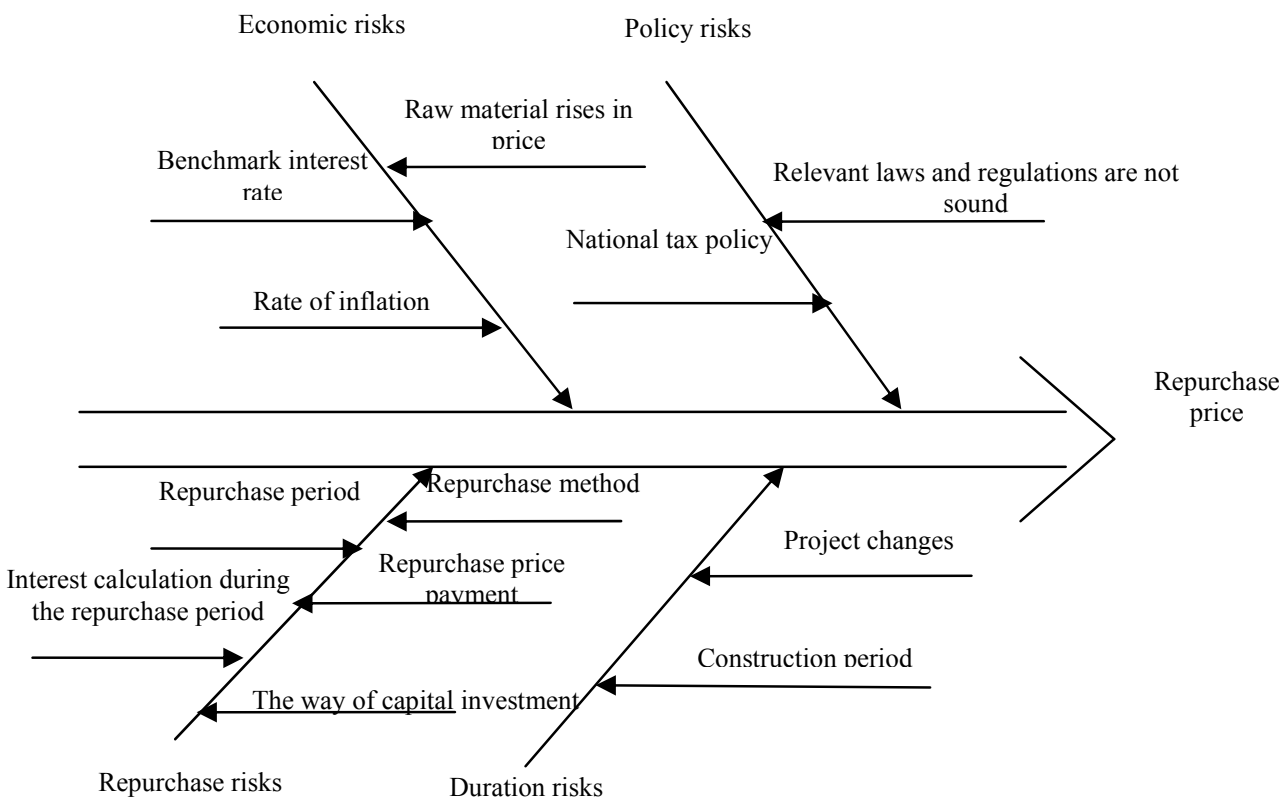

Figure 2. Fishbone diagram of determining the repurchase price

From the graph above we can analyse and draw the conclusion of the classification of risks in the repurchase price, as well as the further factors influencing these risks. The result of these factors is reflected on the repurchase price. So the owner's control of risks in the repurchase stage is also reflected on the control of the repurchase price. How to determine the repurchase price will be discussed in the next section.

\section{DETERMINE THE INCOME FROM INVESTMENTS IN THE REPURCHASE PERIOD}

The profits of the repurchase period are the price apart from the repurchase price in the repurchase period paid by the owner. The size of it is related to the way of BT repurchase, the repurchase period, the rate of return on investment and other factors. As mentioned in literature [6], generally there are two ways of payment of the BT repurchase price. Then the repurchase mode in the two repurchase payment is discussed. Assuming the BT repurchase base price for $C$, annual investment rate of return for $r$, the repurchase period for $m$ year, the repurchase time interval for $\mathrm{n}$ year, so the times of repurchase are $\mathrm{k}=\mathrm{m} / \mathrm{n}$, the calculation formula of repurchase priceC, if according to the equal principal, the formula of calculating the repurchase total price is:

$$
C C+D C+O C+\left[\sum_{n=1}^{T}\left(\sum_{t=1}^{N} A_{t} \times \frac{T_{t}}{360} \times R_{\mathrm{t}}\right)\right](1-1)
$$

If according to the equal principal and interest, the formula of calculating the repurchase total price is:

$$
C C+D C+O C+\sum_{n=1}^{T}\left(\sum_{t=1}^{N} A_{t} \times \frac{T_{t}}{360} \times R_{\mathrm{t}}\right)(1-2)
$$

Type (1-2), $\eta$ is investment return coefficient, which is usually determined by BT project owner.

With the formula determined by the total repurchase price of BT project in different repurchase payment[7], BT repurchase return model can be established no matter how much the BT project repurchase price is[8]. It will ultimately meets both the owner and the Contractor's goal, and it is the constraint conditions of objective function. It is assumed that there is only one goal for the owner: Mathematical model of BT owner's repurchase price was established as shown above: object function $\mathrm{F} \equiv \mathrm{Min}\{$ total price of repurchase $\}(1-4)$

S.T. constraint

Own capital FIRR of the BT host $\geq$ The requirements of a financial internal rate of return

The repurchase total price of the BT sponsor $\leq \mathrm{a}$ number that the two sides have agreed in advance

Rate of return on investment the BT sponsor give to the

BT host $\leq$ a number that the two sides have agreed in advance

The proportion of its own funds that the BT sponsor asks the BT host $\geq 35 \%$ or according to what the two sides have agreed in advance

\section{CASE ANALYSIS}

As is mentioned above, to the repurchase base price determined by the calculation, there are different single payment to form different repurchase total price by different 
repurchase period and payment[9]. And the same way of paying by a quarter, half a year, one year are also considered to the payment of the repurchase price. Different repurchase period will form different cycle of calculation financing cost. Paying the repurchase shall be taken the equal principal, as well as the finance cost. The repurchase price is paid by the tenderee within three years (final) form the next day of starting the project operation.

Selecting the different repurchase period, using different methods of payment, calculating similar to above, the corresponding single payables and the total repurchase price can be obtained.

According to this, the project Party A can make some comparative analysis in different repurchase period, in different ways of the repurchase payment and in different ways of the construction payment. The combined effect of factors such as construction period can deduce the different combinations of the repurchase price according to this formula. Under the influence of various factors, the optimum combination scheme based on this should be selected in order to determine the repurchase price and the various factors. The contractor signs the contract and maximizes the utilization of government funds.

According to the case analysis, the main factors effects of the repurchase price is verified as: the payment of investment in the construction period, the construction period, the repurchase price payment, the repurchase financing deadline and return rates. These factors are the joint effect to the repurchase price. Starting from the government side, the government in BT project negotiation process should be based on the main factors that affect the repurchase price. Compare on the choice to the repurchase price, select the optimal combination scheme, and then determine the various factors of the repurchase price.

\section{CONCLUSION}

This paper studied the BT project specific operation process which was divided into determining in the earlier stage, construction in the middle stage and repurchase in the later stage, and analyzed the risk in BT in the operation, proposed the risk sharing scheme according to the owner and the investor, elaborated the BT repurchase period based on the government position and how to control the risk in the repurchase stage. According to the analysis of various factors influencing the repurchase price, the calculation method of repurchase price was determined. The concrete case was also used in this paper to analyse the operation of the project process and simulate the procedure of determining the government repurchase price.

\section{ACKNOWLEDGEMENTS}

This research was supported by Humanities and Social Sciences Foundation of Ministry of Education of China (Grant No, 14YJC630211).

\section{REFERENCE}

[1] Zhang Jijing, The project financing of [M]. second edition. Beijing: CITIC publishing house, 2003

[2] Yu Zhiying, $\mathrm{Hu}$ Jialin.BT construction mode of [J]. water conservancy science and technology and management, 2004 (8): 255-256

[3] Wang Hao.BT Research [J]. on application in infrastructure projects in the macroeconomic , 2005 (10): 34-35

[4] Chen $\mathrm{Hu}, \mathrm{Ye}$ Shaoshuai, Financing mode [J].of railway engineering management of BT infrastructure construction, 2005 (4): 18-2

[5] Wang Chuang. Study on the investment mode of BT [J]. financial research, 2005 (11): 40-42

[6] Zhang Li.BT project investment control study [D]. Nanjing: Southeast University, 2006,4

[7] The International Federation of consulting engineers. China Association of engineering consultants compiler. Design procurement construction (EPC) / Turnkey Contract Conditions of [M]. Mechanical Industry Press, 2002

[8] Chen Jianxiang capital cost of [J].. Journal of Hunan Administration College, 2003 (1): 12-14

[9] Zhang Wenjuan, Wang Guangbin. Determination of rail transit project under the mode of BT cost $[\mathrm{J}]$. construction economy with the method of GMP, 2006,10:23-24 